\title{
УДК 159.98
}

DOI: $10.18523 / 2617-2348.2020 .3 .36-41$

Каплуненко Я. Ю.

\section{ПЕРША ПСИХОЛОГІЧНА ДОПОМОГА: ДОСВІД МІЖНАРОДНИХ ОРГАНІЗАЦІЙ}

\begin{abstract}
У статті надано визначення поняття першої психологічної допомоги (ППД) постраждалим унаслідок кризових подій, описано ключові аспекти, структуру, часові межі та принципи діяльності; розглянуто три провідні моделі надання першої психологічної допомоги в контексті діяльності міжнародних медичних організацій: Всесвітньої організаиії охорони здоров'я (ВООЗ), «Лікарі без кордонів» (Médecins Sans Frontières, MSF), Центру охорони здоров'я імені Джонса Гопкінса (США). Описано RAPID-модель надання периої психологічної допомоги та ключові компетенції прачівників психосочіальної сфери, залучених до допомоги постраждалим.
\end{abstract}

Ключові слова: перша психологічна допомога, психосоціальна підтримка, стрес, кризова інтервенція, травматична подія, хронограма психічних реакцій, RAPID-модель.

Буремні потрясіння останніх десятиліть: збільшення кількості техногенних катастроф, природних руйнувань, глобальна політична дестабілізація та воєнні конфлікти, а також поява нового виклику для людства - пандемії - актуалізують потребу мінімізувати втрати та завдану шкоду, підтримати людей у непрості моменти їхнього життя, тому психосоціальна підтримка постраждалих $є$ пріоритетним та невідкладним завданням. Для планування ППД та підготовки осіб, які можуть іiі надавати, розроблено низку керівництв на загальносвітовому та державному рівнях, а також у межах міжнародних медичних товариств 3 надання допомоги постраждалим. Від якості та швидкості перших психосоціальних інтервенцій залежить швидкість відновлення постраждалих, стабілізація їхнього психологічного стану та розв'язання їхніх проблем.

Метою цієї статті є огляд основних підходів до надання першої психологічної допомоги постраждалим унаслідок кризових подій. На сьогодні у світі розроблено близько 30 керівництв, які, відрізняючись деталями, грунтуються, менше з тим, на схожих принципах, а саме: безпеці, заспокоєнні, поєднуванні, самоефективності та надії. Узагальнюючи засадничі принципи, варто зазначити, що ППД грунтується на базовому підході «не зашкодь» та охоплює інформування, захист, емоційне піклування та покрокову практичну підтримку [9].

Уперше термін «перша психологічна допомога» було використано в монографії Американської психіатричної асоціації (1954), де було зазначено, що під час будь-яких катастроф,

(C) Каплуненко Я. Ю., 2020 природних чи ворожих нападів, люди зазнають стресового навантаження, якого немає в буденному житті, тому важливо, щоб усі працівники рятувальних служб були ознайомлені із загальними закономірностями реакції на надзвичайний емоційний стрес, а також знали фундаментальні принципи ефективної допомоги постраждалим людям.

У 1950-1960-ті роки інтерес до кризових інтервенцій був незначний, допомогою під час кризових подій у цей період займалася міжнародна медична організація «Червоний Хрест», до складу якої входили висококваліфіковані лікарі, що працювали в місцях катастроф. Ця система загалом добре функціонувала, але 2005 рік став поворотним, оскільки найбільш руйнівний в історії США ураган «Катріна» спустошив узбережжя США, спричинивши значні руйнування та численні людські жертви, що виявило гостру потребу розбудови внутрішніх ресурсів відновлення громад та розроблення надійної системи підтримки психічного здоров'я. Починаючи з 2005 року у світі було розроблено понад 30 керівництв 3 надання першої психосоціальної допомоги [3].

У більшості країн також створено багаторівневі системи допомоги постраждалим від конфліктів та інших руйнувань. Їхньою метою $є$ не лише психосоціальна підтримка окремої особи, а й відновлення психологічного здоров'я та благополуччя громад.

Найвідомішим і найпоширенішим є Керівництво ВООЗ з ППД для працівників на місцях (2009), створене відповідно до Резолюції 
Генеральної Асамблеї ООН (46/182) від 19 грудня 1991 року щодо зміцнення координації надання невідкладної гуманітарної допомоги в умовах складних надзвичайних ситуацій та стихійних лих. До розроблення цього документа долучилися й інші організації, зокрема Фундація травми війни та World Vision International (Велика Британія). Керівництво схвалено 24 міжнародними громадськими організаціями та підрозділами ООН, перекладено 33 мовами, зокрема й українською. За визначенням BOO3, перша психологічна допомога (ППД) - гуманна, підтримуюча та практична допомога людям, які нещодавно постраждали від дії значних стресових чинників. ППД охоплює: ненав'язливе надання практичної допомоги та підтримки; оцінювання потреб і проблем; надання допомоги в задоволенні базових потреб (іжа, вода, одяг); уважне слухання, не примушуючи людей говорити; втішання та заспокоєння; надання доступу до інформації, послуг та соціальної підтримки; захист від подальшої шкоди. У керівництві відображено такі аспекти:

- що являє собою ППД;

- що варто знати, коли ми стикаємося з травматичною ситуацією;

- як поводитися в кризових ситуаціях, щоб не завдати шкоди собі та іншим;

- ключові опорні елементи ППД;

- хто потребує більш серйозної допомоги;

- ефективні комунікативні стратегії;

- початок та закінчення контакту;

- як попіклуватися про себе та членів своєї команди [8].

Принципи та техніки ППД відповідають чотирьом базовим стандартам:

1) грунтуються на результатах досліджень ризиків та стійкості після травми [2];

2) практичні та придатні для застосування в «польових умовах»;

3) відповідають віковим особливостям розвитку;

4) враховують культурні відмінності.

Надають ППД учасники мобільних бригад 3 допомоги постраждалим, рятувальники, пожежники, соціальні працівники, волонтери, медичні працівники, представники місцевих громад, учителі, а також перші постраждалі, які можуть опанувати себе. Ці знання також корисні й для широкого загалу як методи підвищення особистої компетентності в ситуаціях невизначеності та для зміцнення стійкості громад.

Протягом останніх десятиліть дослідники приділяють достатньо уваги психосоціальним наслідкам кризових подій: природних та техногенних катастроф, воєн, епідемій [6], що стимулювало розвиток стратегій ранніх інтервенцій, щоб пом'якшити їхній руйнівний вплив та запобігти довготривалим негативним наслідкам. В історичному контексті серед таких екстрених психологічних втручань можна виділити психологічний дебрифінг, або техніку перегляду та інтеграції досвіду, розроблену американським психологом Д. Мітчеллом у 1983 році для працівників аварійно-рятувальних служб, а згодом iї почали застосовувати і для цивільних постраждалих. Однак більш пізні дослідження вказували на те, що цей метод не для всіх людей був корисним у контексті довготривалих наслідків, а іноді навіть призводив до погіршення психологічного стану та ретравматизації жертв [9]. Тому в подальшому зупинилися на більш виважених моделях допомоги, зокрема ППД, яка спиралася на стрижневі елементи відновлення, а саме: людям стає краще 3 часом, якщо вони почуваються в безпеці, взаємодіють 3 іншими, заспокоюються та віднаходять надію; мають доступ до соціальної, матеріальної та емоційної підтримки; відновлюють відчуття контролю завдяки здатності допомогти самим собі [8].

Для ефективного надання ППД працівникам на місцях важливо керуватися основними принципами, а саме:

- готуватися,

- дивитися,

- слухати,

- поєднувати.

Готуватися - означає зібрати якнайбільше інформації про конкретну кризову подію, про доступні служби надання психосоціальних послуг та підтримки, особливості безпеки та охорони.

Дивитися - означає наглядати за безпекою, власною та інших людей, розпізнавати тих, хто потребує невідкладного піклування та задоволення базових потреб, і постраждалих з ознаками значних стресових реакцій.

Слухати - передбачає встановлення контакту 3 тими, хто може потребувати підтримки, прояснення їхніх потреб і тривог, активне слухання та заспокоєння.

Поєднувати - означає допомагати постраждалим у задоволенні базових потреб та доступі до служб надання психосоціальних послуг, у подоланні їхніх проблем; інформувати й поєднувати з родичами та колом соціальної підтримки.

Здебільшого люди добре відновлюються з часом (до 90 \%), особливо якщо задовольняють базові потреби і одержують підтримку (ППД). 
Постраждалі з тяжким чи довготривалим стресом можуть потребувати більшої підтримки, тому важливо переконатися, що вони не залишаються на самоті, й, за потреби, потурбуватися про перебування їх у безпеці, доки не мине реакція або ж не знайдеться допомога інших людей. Під час взаємодії важливо допомогти людям почуватися спокійно, стишувати голос, говорити спокійним тоном, підтримувати зоровий контакт, запевнити, що вони в безпеці, або, принаймні, ви є поряд, щоб допомогти. У разі дисоціативних проявів треба відновити контакт постраждалого із самим собою, власним тілом (відчути ноги на підлозі, поплескати долонями по колінах), своїм оточенням (помітити речі довкола), своїм диханням (зосередитися на диханні та дихати повільно).

У стресовому стані люди зазвичай мають хаотичне мислення і почуваються перевантаженими турботами, їм важко подбати про себе, тому важливими ланками допомоги є пріоритизація нагальних потреб (що треба зробити насамперед); практичні рекомендації щодо їх задоволення (наприклад, реєстрація для отримання їжі, одягу тощо); визначення особистих джерел підтримки, відновлення віри в себе, визначення ресурсних зон та зміцнення здатності попіклуватися про себе [8]. Стрес - широке поняття, яке охоплює багато різних значень: реакція організму на зміни, що потребують фізичного, емоційного та психологічного переналаштування; будь-які зміни у нашому внутрішньому чи зовнішньому середовищі, до яких ми маємо адаптуватися; негайна, біологічна, фізіологічна та психологічна тривожна реакція людини під час зіткнення з агресією або загрозою. Механізм стресу еволюційно має позитивне значення, оскільки змушує нас зосередитись на загрозливій ситуації, мобілізує енергію для оцінювання й прийняття рішень. Рівень стресу має значення: якщо він недостатній - люди можуть втратити мотивацію, якщо надмірний (висока інтенсивність, довга тривалість або повторюваність впливу), то виснажуються, і їхня активність страждає. Оптимальним для життєдіяльності є середній рівень стресу.

Травматичний стрес $є$ наслідком раптових, непередбачуваних та руйнівних подій, що зазвичай, поза межами звичайного життєвого досвіду, можуть загрожувати життю, благополуччю або гідності людини і призводити до стану шоку, оніміння, безсилля та безпорадності, до зниження здатності постраждалих виживати та адаптуватися. У всіх стресових ситуаціях виникають реакції, спільні для всіх людей (фізіологічні, поведінкові, емоційні, когнітивні), проте вони можуть по-різному проявлятися залежно від обставин. Фізіологічні реакції - тахікардія, пітливість, гастрит, гіперсекреція, виснаження, головні болі, розлади сну, проблеми зі шлунком, пришвидшене дихання; поведінковi - гіпер/гіпоактивність, гарячковість, надмірне вживання алкоголю, втрата апетиту / переїдання; дрібні ушкодження, нервові тики, агресивність, плач, складнощі з висловлюванням; емоційні - тривога, смуток, відчай, розпач, знервованість, страх, напруга, розчарування; когнітивні - проблеми 3 концентрацією, занепокоєність, тяжкі думки, зневіра, безпорадність, складність у прийнятті рішень, зажуреність, байдужість, мрійництво.

У різних людей прояви стресових реакцій можуть бути різними, так само може відрізнятися реакція однієї й тієї самої людини в різні моменти часу, на різні подразники. Це залежить від функціонального стану організму, зовнішніх і внутрішніх ресурсів людини та підтримувальних чинників.

Хронограму психічних реакцій на стресову подію та надання ППд допомоги постраждалим у межах міжнародних медичних організацій поділяють на чотири фази: фаза 1 (24 години), фаза 2 (1-3 дні), фаза 3 (1-4 тижні), фаза 4 (1-3 місяці).

ФАЗА 1 (24 години). Для постраждалих характерні звичайні гострі реакції на надмірну стресову подію: напруженість, тривога, паніка; приголомшеність, зневіра, розпач; ейфорія «тих, що вижили»; занепокоєність, розгубленість; перезбудження, плач, закляклість; провина «того, хто вижив» тощо. На цьому етапі основне завдання осіб, які підтримують, - структурування хаосу: «Будьте як батьки». Фокусом допомоги постраждалим $є$ задоволення базових потреб та практична підтримка, а саме: дати поїсти чи попити, підтримати під час розмови $з$ представниками мас-медіа чи поліцією, допомогти зв'язатися з родиною, надати емоційну підтримку, уможливити розповідь про подію, вислухати без засудження та недоречних запитань, не виявляти надмірної допитливості, проясняти потреби; визнавати почуття (страх, злість, сум); підготувати до можливих порушень сну та інтрузій (нав'язливих думок, снів), допомогти нормалізувати симптоми; за можливості домовитися про наступну зустріч. У більшості постраждалих такі реакції згодом минають.

ФАЗА 2 (1-3 днi). Основні реакції постраждалих на цьому етапі: боязкість, надпильність, настороженість (дратівливість, злість, розлади сну); 
стурбованість, зневіра, інтрузії, флеш-беки; смуток; позитивні реакції (надія, планування подальших дій, участь у відновлювальних роботах, піклування про інших); прийняття «природності» події як частини життя. Не всі реакції постраждалих є неадаптивними, або потрібні незначні психосоціальні втручання, щоб вони нормалізувалися. Основним завданням цієї фази є емоційна підтримка та психологічна просвіта: «Будьте як учитель». Фокус допомоги - уважне слухання та заохочення постраждалого й родини до побудови розповіді про подію, допомога в узагальненні інформації, прояснення того, що сталося. За наявності попередніх травм важливо їх визнати, але поки що глибинно не обговорювати, пізніше вони можуть бути опрацьовані в психологічному центрі. Наступним кроком є складання розповіді (наративу) про подію і більш грунтовна психологічна просвіта: підготовка сім’ї та постраждалого до можливих реакцій оточення (недоречні жарти, допитливість тощо), навчання навичок саморегуляції та позитивних стратегій подолання.

ФАЗА 3 (1-4 тижні). У цій фазі у постраждалих можуть тривати попередні симптоми, крім того, проявлятись неспокій, паніка, інтенсивний смуток, розпач, нереалістична катастрофізація майбутнього; бездіяльність, ізольованість, закритість; тривожні прояви (запаморочення, нудота, пришвидшене серцебиття, головний біль, неспокій тощо). Для психосоціальних працівників метафорою допомоги в цій фазі є: «Будьте як терапевт», що передбачає більш складний рівень когнітивно-емоційної підтримки: перевірка симптомів і тяжкості проблем від першого дня до сьогодні (погіршення, поліпшення); чи досі є прояви надпильності, уникання, перепроживання досвіду і порушень сну; перевірка розпорядку дня, чи відповідає він тому, який був до травми. Будь-що, що повертає людині відчуття контролю, безпеки, справедливості та передбачуваності, є корисним та має заохочуватися. Негативні копінг-стратегії підтримувати не варто, але без засудження, їх слід визнати як спроби подолання, але $з$ пошуком альтернативних, більш адаптивних, стратегій.

$\Phi A 3 A 4$ (1-3 місяиі). На цьому етапі зазвичай постраждалі з достатньою психологічною здатністю до відновлення вже повертаються до свого звичного життя, майже як і до події. У разі тривання симптомів доцільними будуть грунтовніша емоційна підтримка та психологічна просвіта i, за потреби, психотерапевтичний супровід. «Будьте тим, хто допомагає віднайти сенс».
Основним завданням холістичного підходу на цьому етапі є складання точного і стислого наративу про подію, без надмірної деталізації та емоційних реакцій; віднайдення сенсу подальшого життя, психологічна підготовка постраждалих до можливого поновлення симптомів у дати, близькі до пережитої події. Якщо контроль над тілесними реакціями та думками в постраждалих відновлено; наратив події завершений та супроводжується відповідними емоційними реакціями, емоції прийнято, самооцінку та впевненість у собі відновлено та з'явилося відчуття майбутнього, можна сказати, що людина успішно адаптувалася до травматичної події й готова рухатись далі [5, p. 31-35].

Дж. С. Еверлі (George S. Everly, Jr.) та Дж. М. Летінг (Jeffrey M. Lating) розробили іншу модель надання ППД - «RAPID PFA», ставлячи за мету створити простий і доступний у використанні, практичний метод. За цією моделлю нині проводиться навчання спеціалістів на базі Університету Джонса Гопкінса (Johns Hopkins Center for Public Health Preparedness), США.

Основу цієї моделі складають п'ять аспектів, призначених для пом'якшення гострого стресу та оцінювання необхідності подальшої психологічної допомоги:

1) співналаштування та активне слухання (Rapport and Reflective listening);

2) оцінювання потреб (Assessment of needs);

3) пріоритизація (Prioritization);

4) інтервенція (Intervention);

5) диспозиція (Disposition).

$\mathbf{R}$ - встановлення стосунків, налаштування та рефлексивне слухання. Немає однакових людей та однакових ситуацій, тому не варто бути самовпевненим та упередженим. У багатьох випадках люди самі скажуть про те, чого потребують, можуть підказати, як краще допомогти. Потрібні неупередженість, співчуття та присутність.

А - швидке оцінювання потреб: здатність швидко, майже одразу, визначити, хто страждає на гострий стрес, а хто - ні. Це не формальна діагностика, а розпізнавання тих, хто потребує допомоги, а хто перебуває в більш стабільному стані.

$\mathbf{P}$ - пріоритизація: визначення найнагальніших завдань.

I - втручання: що можна зробити зараз, щоб стабілізувати стан людини, пом'якшити гостре страждання. Що я можу зробити, щоб допомогти? Потрібно мати конкретні стратегії втручання. Що ми можемо сказати та зробити, щоб відкрити дорогу до зцілення? 
D - диспозииія. Налагодивши стосунки та взаємозв'язок, щоб прояснити нагальні потреби, ми дослухаємось до людей, оцінюємо необхідність втручання, надаючи пріоритет тим, хто потребує невідкладної допомоги. Стабілізувавши постраждалого, ми й надалі спостерігаємо, як поводиться людина, чи здатна вона повернутися до звичного рівня функціонування, чи, може, ще чогось потребує. На думку розробників, ППД не має бути одноразовим втручанням, допомога постраждалим передбачає тривале спостереження, догляд та залучення інших форм психосоціальної підтримки [4].

Висновки. Серед компетенцій, необхідних для надання першої психологічної допомоги, виділяють: навички активного слухання (навички невербального слухання; ефективне перефразування; емпатія та точне визначення проявлених емоцій); навички оцінювання симптомів (навички розпізнавання базових стресових реакцій); навички управління стресовими реакціями (релаксаційні техніки, техніки емоційної саморегуляціï); здатність розрізняти адаптивні та дезадаптивні копінг-стратегії, потребу в терміновому втручанні; уміння виявляти та активувати джерела міжособистісного спілкування та підтримку, використовувати кризові комунікативні стратегії, відповідальність та усвідомлення можливості створити ще більший дистрес; вміння подбати про себе та членів своєї команди [7].

\section{Список джерел}

1. Основи реабілітаційної психології: подолання наслідків кризи : навч. посіб. [Електронний ресурс] / заг. ред. Н. Пророк. - Т. 1. - Київ, 2018. - 208 с. - Режим доступу: https:// www.osce.org/uk/project-coordinator-in-ukraine/430805? download=true. - Назва з екрана.

2. Galea S. The epidemiology of post-traumatic stress disorder after disasters / S. Galea, A. Nandi, D. Vlahov // Epidemiologic Reviews. - 2005. - Vol. 27(1). - P. 78-91. https://doi.org/10.1093/ epirev/mxi003

3. Everly G. Principles and practical procedures for acute psychological first aid training for personnel without mental health experience / G. Everly, B. Flynn // Int J Emerg Ment Health. - 2006. - Vol. 8. - P. 93-100

4. Everly G. The development of a model of psychological first aid for non-mental health trained public health personnel: The Johns Hopkins RAPID-PFA / [G. Everly, J. McCabe, N. Semon et al.] // Journal of Public Health Management and Practice. 2014. - Vol. 20. - P. S24-S29. https://doi.org/10.1097/PHH. 0000000000000065

5. Mental health in primary health care. A training course for MSF medical staff. - 2012. - 186 p. - (MSF Mental Health International Working Group).

6. Norris F. 60,000 disaster victims speak: Part II. Summary and implications of the disaster mental health research / F. Norris, M. Friedman, P. Watson // Psychiatry. - 2002. - Vol. 65. P. 240-260. http://dx.doi.org/10.1521/psyc.65.3.240.20169

7. Psychological First Aid: Field Operations Guide [Electronic resource] / Terrorism and Disaster Branch National Child Traumatic Stress Network. - Mode of access: http://www. ncptsd.va.gov/ncmain/ncdocs/manuals/smallerPFA_2ndEditio nwithappendices.pdf. - Title from the screen.

8. Psychological First Aid: Guide for field workers [Electronic resource] / World Health Organization (WHO) \& War Trauma Foundation and World Vision. - 2011. - Mode of access: https://www.who.int/publications/i/item/9789241548205. Title from the screen.

9. Shultz J. Psychological First Aid Rapid proliferation and the search for evidence / J. Shultz, D. Forbes // Disaster Health. 2013. - Vol. 2. - P. 1-10. http://dx.doi.org/10.4161/dish.26006

\section{References}

1. Prorok, N. (Ed.). (2018). Osnovy reabilitatsiinoi psykholohii: podolannia naslidkiv kryzy. Vol. 1. Kyiv. https://www.osce. org/uk/project-coordinator-in-ukraine/430805?download=true [in Ukrainian].

2. Galea, S., Nandi, A., \& Vlahov, D. (2005). The epidemiology of post-traumatic stress disorder after disasters. Epidemiologic Reviews, 27(1), 78-91. https://doi.org/10.1093/epirev/mxi003

3. Everly, G., \& Flynn, B. (2006). Principles and practical procedures for acute psychological first aid training for personnel without mental health experience. Int J Emerg Ment Health, 8(2), 93-100.

4. Everly, G. S., McCabe, O. L., Semon, N. L., Thompson, C. B., \& Links, J. M. (2014). The Development of a Model of Psychological First Aid for Non-Mental Health Trained Public Health Personnel: The Johns Hopkins RAPID-PFA. Journal of Public Health Management and Practice, 20, S24-S29. https:// doi.org/10.1097/PHH.0000000000000065
5. MSF Mental Health International Working Group. (2012). Mental health in primary health care. A training course for MSF medical staff.

6. Norris, F., Friedman, M., \& Watson, P. (2002). 60,000 disaster victims speak: Part II. Summary and implications of the disaster mental health research. Psychiatry, 65, 240-260. http://dx.doi. org/10.1521/psyc.65.3.240.20169

7. National Child Traumatic Stress Network and National Center for PTSD. (2005). Psychological First Aid: Field Operations Guide. http://www.ncptsd.va.gov/ncmain/ncdocs/manuals/smal lerPFA_2ndEditionwithappendices.pdf

8. World Health Organization (WHO) \& War Trauma Foundation and World Vision. (2011). Psychological First Aid: Guide for field workers. https://www.who.int/publications/i/item/9789241548205

9. Shultz, J., \& Forbes, D. (2013). Psychological First Aid: Rapid proliferation and the search for evidence. Disaster Health, 2, 1-10. http://dx.doi.org/10.4161/dish.26006 


\section{Y. Kaplunenko}

\section{PSYCHOLOGICAL FIRST AID: EXPERIENCE OF INTERNATIONAL ORGANIZATIONS}

The turbulent shocks of recent decades - man-made and natural disasters, political instability, pandemics, and military conflicts - highlight the need for psychosocial support for victims. To plan and train those who can provide it, a number of guidelines have been developed at the global and national levels, within international medical organizations that can minimize the impact of the crisis and start the recovery process. The article presents the definition of the concept of Psychological First Aid (PFA), describes the key aspects, structure, time limits, and principles of activity; a description of three leading models of first psychological assistance in the context of international medical organizations: the World Health Organization (WHO), Doctors Without Borders (Médecins Sans Frontières, MSF), and the Johns Hopkins Center for Public Health Preparedness, USA. The RAPID model of first aid and key competencies for psychosocial workers involved in helping victims are described. The principles and techniques of PFA meet four basic standards: they are based on the results of research of risks and resilience after injury; they are practical and suitable for use in the "field"; they meet the age characteristics of development; they take into account cultural differences. The chronogram of mental reactions to a stressful event and the provision of PFA to victims within international medical organizations is divided into four phases which should be taken into account in the organization of psychosocial support. The RAPID model is based on five aspects designed to alleviate acute stress: Rapport and Reflective listening; Assessment of needs; Prioritization; Intervention; Disposition. If control over bodily reactions, emotions, and thoughts in the victims are restored, the narrative of the event is completed and accompanied by appropriate reactions, emotions are accepted, self-esteem and selfconfidence are restored, and a sense of the future appears, we can say that the person has successfully adapted to the traumatic event and is ready to move on.

Keywords: Psychological First Aid, psychosocial support, stress, crisis intervention, traumatic event, chronogram of mental reactions, RAPID model.

Матеріал надійшов 06.02.2021

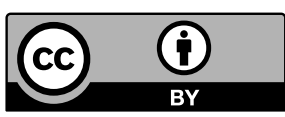

Creative Commons Attribution 4.0 International License (CC BY 4.0) 